\title{
Economic Organization and the Trade-Offs Between Productive and Destructive Entrepreneurship
}

\author{
Kirsten Foss and $\mathrm{N}$ icolai Foss \\ Department of Industrial Economics and Strategy \\ Copenhagen Business School \\ Howitzvej 60 \\ 2000 Frederiksberg \\ Denmark \\ kf.ivs@cbs.dk, njf.ivs@cbs.dk \\ Draft, May 28, 2000
}

\begin{abstract}
A bstract
The connection between entrepreneurship and economic organization is an under-researched topic in the economics of organization. This paper argues that key insights of the Austrian school of economics with respect to entrepreneurship and the nature and role of property rights and ownership may be useful ingredients in the economics of organization. Thus, we show that incorporating Austrian ideas allows to give new answers to such issues as who will be the principal and who will be the agent; how joint surplus in an productive relation will be split and who will own alienable assets.
\end{abstract}

\section{Acknowledgment}

We are grateful to Peter G. Klein, Bo Eriksen, Pierre Garrouste, Thorbjørn Knudsen, Mario Rizzo, and Ron Sanchez for comments and suggestions. 


\section{Introduction}

In the view of Frank Knight (1921) - the founder of the theory of the firm - firm organization, profit, and the entrepreneur are closely related phenomena. In his view, these arise as, respectively, an embodiment, a result and a cause of commercial experimentation (Demsetz 1988a). Very few economists have followed Knight in his linking together the existence of the firm, profit, and entrepreneurship. Notably, entrepreneurship is largely neglected in the modern economics of organization (as in most of modern economics). However, as we shall argue, introducing the notion of entrepreneurship has profound consequences for the understanding of economic organization - in the sense of different systems of property rights (contractual structures, governance structures, ownership) -, consequences that are different, yet complementary to those of the modern economics of organization. ${ }^{1}$

In order to explicate these consequences we take our starting point in ideas and insights associated with the Austrian school of economics, and not just ideas on entrepreneurship. ${ }^{2}$ A neglected chapter in the history of the economics of property rights and ownership is constituted by A ustrian school economists, such as Menger (1871), Böhm-Bawerk (1883), and Mises (1936, 1949). Our aim in this paper is not to provide a detailed historical exegesis of Austrian contributions to property rights theory per se. Rather, we are interested in how some of the characteristics of the A ustrian view of property rights connect to the Austrians' well-known emphasis on entrepreneurship (Hayek 1948, 1968; Mises 1949; Kirzner 1973; O'Driscoll and Rizzo 1985; Lachmann 1986), and how these insights contribute to our understanding of economic organization.

More specifically, one way in which notions of entrepreneurship relate to property rights reasoning (and vice versa) begins from recognizing that assets have multiple attributes (Hayek 1948; Barzel 1997). The attributes of assets include not only known present uses and characteristics, but also uses and characteristics that are presently unknown (at least to some agents) but which may be discovered and created through entrepreneurial action (Knight 1921; Hayek 1948; Shackle 1972; Kirzner 1973). We shall argue that the combination of ideas on entrepreneurship and ideas on property rights yields several implications for economic organization and the modeling thereof. The most important such implications are the following ones.

First, the economist who takes an entrepreneurial starting point must recognize that the contracting space is in principle always open-ended, so that new

\footnotetext{
1 For two companion papers, of more methodological nature, to the present paper, see Foss (1999) and Foss and Foss (2000b).

2 We don't pretend this paper to be an orthodox Austrian paper, though. There may be much that orthodox A ustrians may take issue with. However, we draw broad inspiration from what we take to bekey Austrian ideas.
} 
margins may be discovered over which agents may optimize their gains. ${ }^{3}$ Second, entrepreneurial discovery of new margins will not necessarily lead to increases in joint surplus; for example, destructive rent-seeking may well be one outcome of entrepreneurial activity. Third, one important function of contracts and property rights systems is to implement the optimal combinations between "productive" and "destructive" entrepreneurial activities, that is, those that increase, respectively decrease, joint surplus. ${ }^{4}$ We present this argument in the context of incomplete contracts, and argue that there are not only costs but also benefits of contractual incompleteness; as agents become less constrained, they are likely to engage in destructive and productive entrepreneurship. Given this, there is an optimal tradeoff between these two types of entrepreneurship that may be implemented through contractual constraints. As we shall argue, this partly accounts for structures of ownership and for the structure of contracts, thus adding determinants of economic organization that complement those traditionally considered in the modern economics of organization (i.e., moral hazard, the hold-up problem). Fourth, because the Austrian perspective suggests that entrepreneurial abilities are unevenly distributed and are likely to be tacit (Hayek 1945), the productive opportunities that can be realized is a function of economic organization. Thus, one property rights arrangement may stimulate entrepreneurial discovery to a greater extent than another arrangement. As we argue, this means that who will be the principal and who the agent in a productive relation has efficiency implications an issue that is not treated in the standard principal-agent story.

The design of the paper is as follows. We begin by briefly discussing the notion of entrepreneurship in Austrian economics, and by pointing out that A ustrians were among the first economists to take an interest in property rights and ownership as economic categories. We emphasize that entrepreneurship and property rights are complementary concepts, and that one way in which to bring the concepts into closer contact springs from the notions that most productive assets are multi-attribute in nature and that entrepreneurship may be understood as the discovery and capture of rights to valued attributes of such assets. As we define it, when an individual captures economic rights (i.e., takes control over attributes) that reduces joint monetary surplus he is engaging in destructive entrepreneurship; when capture increases surplus, he is engaging in productive entrepreneurship (Section II, "Entrepreneurship and Property Rights"). We then show that Austrian perspectives on how property rights, ownership and entrepreneurship can be modeled by means of a simple example, in which efficient economic organization selects an optimal combination of destructive and productive entrepreneurship. It is also possible, in the context of the example, to determine which one of two

\footnotetext{
3 See Foss and Foss (2000b) for a discussion of how this heuristic contrasts with the conventional modeling approach in contract theory. Of course, in actual modeling, contracting spaces are somehow closed, because of the immense mathematical complexities of working with open spaces. We invoke the notion of an open contracting space as a feature of the interpretation and application of the model.

4 These are Baumol's (1990) terms. For a discussion of the value issues that are involved here, see Ricketts (1987).
} 
entrepreneurial individuals will assume the role of principal and who of agent; how they will share the surplus, and who will own the asset in the relation (section III, "Implications for Economic Organization"). We finally discuss how our approach relates to and differs from other approaches to economic organization (Section IV, "O ther A pproaches to Economic O rganization").

\section{Entrepreneurship and Property Rights}

\section{Entrepreneurship: Substantive and M ethodological Implications}

Modern Austrian economists (notably Hayek 1968; Kirzner 1973, 1997; Lachmann 1986; O'Driscoll and Rizzo 1985; Littlechild 1986) view the market as an ongoing process of discovery. In this conception, agents' plans are based on incomplete, imperfect and subjectively held knowledge about the plans of other agents. Crucially, agents' ignorance goes beyond the conventional asymmetric information paradigm to also include sheer ignorance (Kirzner 1997; Foss 1999). This results in behavior that is off the equilibrium path and in the emergence of disequilibrium prices. However, alert entrepreneurs “... grasp the opportunities for pure entrepreneurial profit created by temporary absence of full adjustment" (Kirzner 1997: 69), so that a "... systematic process is created in which market participants acquire more and more accurate and complete mutual knowledge of potential supply and demand attributes" (idem: 62; emph. in original). In this scheme, equilibrium is seen as "the complete absence of sheer ignorance." Although equilibrium in this sense is, according to the Austrians, never reached, there is a systematic tendency towards equilibrium because of the crucial underlying claims that everybody possesses entrepreneurial abilities (albeit to differing extents) so that agents do have a tendency to discover those margins over which they can optimize. ${ }^{5}$ An entrepreneurial perspective contains both methodological and substantive implications for the theory of economic organization, as we argue next.

Thus, in the context of the theory of economic organization, taking an entrepreneurial starting point means recognizing that the contracting space is in principle always open-ended; the analyst should allow for the possibility of surprise and discovery (Littlechild 1986). ${ }^{6}$ While many may agree on an abstract level with the idea of such open-ended'ness, controversy may arise over how this should be reflected in modeling. For example, it may be argued to conflict with the Savage notion of "small worlds," and hence make the calculation of expected utility — for example, from a principal-agent relation - impossible (cf. Macleod 1994). However, a way around these problems is to argue that decision-makers deliberately construct closure around decision problems in order to make consistent

\footnotetext{
5 However, this tendency to discover hitherto unnoticed opportunities for gain is by no means automatic or perfect. In Kirzner's view, the economy is at any moment characterized by widespread ignorance, and many profit opportunities are simply never exploited.

6 See Foss and Foss (2000b) for a discussion of how this heuristic contrasts with the conventional modeling approach in contract theory.
} 
plans (although they may still be ignorant of many things) and that they optimize relative to what they believe to be important to their plans, taking into account the possibility that plans may be overthrown by unexpected contingencies. Thus, one can have optimization and (ex ante) equilibrium in an open-ended setting (Hayek 1937). This means that contracting entrepreneurs may enter into what they believe on an ex ante basis to be optimal contracts.

With respect to substantive implications for the theory of economic organization, it should be noted that the Austrian (Kirznerian) view of the entrepreneurial market process is painted with a broad brush, and that little specific is actually being said about both the nature of alertness and the market process. Because of this, critics have interpreted alertness as little more than luck (Demsetz 1983). ${ }^{7}$ Although the emphasis on alertness have brought many fruitful insights (cf. Kirzner 1997), it is arguably narrow to identify entrepreneurship only with alertness. Entrepreneurs also create plans based on imagination (Shackle 1972; Witt 1998) and judgment (Knight 1921). We find it a challenging and worthwhile task to incorporate such notions of entrepreneurship into the theory of economic organization, because they direct our attention to substantive phenomena that so far have not been treated in the theory of economic organization, such as, we will argue, the potentially beneficial aspects of contractual incompleteness and the efficiency implications of who in a relation will assume a directing role. One way in which entrepreneurship and economic organization may make contact is via insights in the allocation of property rights. As we discuss next, this is a particularly fitting starting point, since Austrian school economists are important precursors of modern property rights economics.

\section{A ustrian Precursors of Property Rights Economics}

Since Coase's (1960) seminal paper, the notion of property rights has become increasingly important in modern economics. Coase's paper gave rise to a spate of work in the 1960s and the beginning of the 1970s on property rights systems and the theory of the firm (Alchian 1965; Demsetz 1967; Alchian and Demsetz 1972). A more recent, and in many ways different approach to property rights, based more on game theory than on price theory, emerged with Grossman and Hart (1986), and now arguably defines the way in which the modern formal economist thinks about property rights and ownership. ${ }^{8}$ However, property rights economics goes back longer in time than Coase (1960). Thus, it has often been noted that Knight (1924) included property rights considerations in his critique of Pigovian welfare economics. However, a number of Austrian school economists constitute an

\footnotetext{
7 Moreover, there is an implicit claim that the equilibrium towards which the market process is heading is an optimal one - a claim which is problematic given that very little specific is being said in this theory about market dynamics (e.g., the resulting equilibrium may be sensitive to the order of play), institutions (e.g., incentives for entrepreneurship depend on property rights), and the interaction between dynamics and institutions (e.g., how property rights structures enhance and constrain entrepreneurial activity).

8 Foss and Foss (2000a) compare the two approaches.
} 
important, but neglected chapter in the history of property rights economics. This is not the place to engage in a detailed historical exegesis, but it is worth noting that the Austrians held somewhat unconventional views of property rights and ownership, views that in many ways dovetail with the entrepreneurial perspective that we detail later.

Thus, Menger (1871) begins (conventionally) by defining property rights as economic categories, arising out of scarcity, and then moves on (unconventionally) to noting that ownership affords flexibility in the face of uncertainty. For example, he observes that fire extinguishers and medicine chests are owned precisely because of the unpredictability of the relevant states of nature (cf. also Littlechild 1986 and Loasby 1999). Böhm-Bawerk (1883) provides a lengthy and sophisticated discussion of the relation between the law, ownership and property rights. Mises (1936: 27) points out that ownership refers to "the power to use economic goods," and he emphatically stresses that "... the economic significance of the legal should have lies only in the support it lends to the acquisition, the maintenance and the regaining of the natural having" (emphasis in original). In a later work, he noted the connection between property rights and externalities (Mises 1949: 654-655), and rationalized the emergence of various institutions of property in terms of considerations of changing scarcities (1949: 650, 678, 679) (Foss 1994). These Austrian insights on property rights have not been fully assimilated into mainstream property rights economics, but contain important lessons for the economics of organization. Thus, in the works of the older Austrians we find the ideas that ownership of assets may "protect" against uncertainty, that a primary purpose of the institution of ownership is to allocate rights to new uses of owned assets, and that there is fundamental distinction between economic and legal rights. None of these insights are mainstream property rights economics insights. ${ }^{9}$ Certainly for historical reasons, we may take them to be distinctively Austrian insights. In the following sections, we briefly explicate these Austrian insights, explaining in the process how they dovetail with notions of entrepreneurship.

\section{Legal Ownership and Economic Rights}

Considered from an economic point of view, what does it mean to own an asset? Until the publication of Coase (1960), this issue was largely neglected. Much of the post-Coasian property rights literature (e.g., Alchian 1965; Demsetz 1964, 1967; Alchian and Demsetz 1972; Barzel 1987, 1994, 1997; Umbeck 1981) dealt with the meaning of ownership, the relationship between property rights and ownership, and the importance of legal considerations for understanding ownership. However, no clear understanding emerged of issues such as how much exclusivity over uses of assets is required before one qualifies as "owner"; what determines the observed concentration of different types of rights in the hand one agent; and what is the role played by legal considerations in the understanding of ownership (see Foss and Foss 2000a). A main ambiguity in the literature concerns the extent to which

9 Which is not to say that they have been completely absent from the property rights literature. For example, Barzel (1997) puts much stress on the distinction between economic and legal rights. 
ownership is defined by the recognition by others of a claim to ownership, that is, the extent to which exclusivity is based on a (explicit or implicit) recognition by other parties of the property rights of the owner or by the owner's own ability to maintain exclusivity.

One may attempt to solve this ambiguity in various ways. One is to drop the concept entirely for purposes of economic analysis (while recognizing that the concept makes perfect legal sense), and instead concentrate exclusively on property rights (as in Coase 1960). However, an Austrian perspective suggests that this strategy run into problems in the face of unforeseen uses of assets. In this case, there is a need for an institution that allocates these use rights (see later). In fact, this institution is the one that is normally called private ownership. A second strategy is to adopt a working definition of ownership as always comprising a certain minimum bundle of property rights, irrespective of time, place and institutions (e.g., Alchian 1965). A third strategy is to identify ownership with claims to exclusivity that are privately enforced and/ or are enforced by various legal and non-legal institutions. This strategy makes ownership contingent on what is seen as constituting a recognized claim (Umbeck 1981), so that ownership essentially becomes an expectation that an agent holds with respect to his ability to use and receive income from certain assets. We shall argue that this expectation depends not only on enforcement issues (i.e., the traditional focus of the property rights literature) but also on entrepreneurship.

\section{A ttributes, Entrepreneurship, and O wnership}

In order to see how entrepreneurship connects to issues of property rights and ownership, it is convenient to take the work of Barzel $(1987,1994,1997,1999)$ as a starting point. He consistently defines notions of property rights and ownership in terms of expectations. This is highly consistent with the Austrian emphasis on subjectivism (e.g., O'Driscoll and Rizzo 1985). Thus, Barzel (1994: 394; emphasis in original) defines, echoing Mises (1936: 27), a property right as

... an individual's net valuation, in expected terms, of the ability to directly consume the services of the asset, or to consume it indirectly through exchange. A key word is ability: The definition is concerned not with what people are legally entitled to do but with what they believe they can do.

And like Mises, Barzel stresses the importance of the distinction between legal and economic rights. Whereas the former refers to a legally recognized holding of a title to an asset, the latter refers to those property rights over the attributes of an asset that agents expect to control. Attributes are characteristics and possible uses of assets. ${ }^{10}$ A gents then may have different degrees of control over attributes of assets and thus more or less secure property rights over the asset.

\footnotetext{
10 Thus, the notion of "attributes" strictly speaking also covers contingent goods. But often it is most convenient to think of attributes as the various functional characteristics of an asset or as the single physical components of an asset.
} 
Most assets are multi-attribute in nature. Although Barzel stresses property rights to known attributes of assets as the relevant units of analysis, we think it is important to stress that most assets have multiple non-specified and not yet discovered attributes. This also creates a role for asset ownership that is hard to grasp when entrepreneurship is assumed away. Demsetz points out that the notion of "full private ownership" over assets is "vague," and "must always remain so," because "... there is an infinity of potential rights of actions that can be owned ... It is impossible to describe the complete set of rights that are potentially ownable" (Demsetz 1988b: 19). It is true, of course, that if one thinks of ownership as the possession of a bundle of well specified and enforced rights, the notion of full private ownership is indeed "vague" - at least when new hitherto unimagined attributes of assets may be discovered by al ert entrepreneurs. However, the notion of asset ownership need not be as vague. In particular, this notion might well be indispensable for the analysis of an entrepreneur economy.

The basic reason is that asset ownership confers a bundle of rights, including rights to hitherto undiscovered attributes of the relevant asset. 11 There are two aspects of this, one relating to the acquisition of a bundle of rights, and one relating to capture of hitherto undiscovered attributes. With respect to the former aspect, ownership reduces information, communication and contracting costs relative to a situation in which it was necessary to contract over all these rights. This function of ownership is perhaps particularly visible in an entrepreneurial perspective. ${ }^{12}$ First, ownership eases the process of entrepreneurial arbitraging (Kirzner 1973, 1997)and hence eases the closing of pockets of ignorance in the market-by allowing entrepreneurs to acquire, in one transaction, a bundle of rights to attributes (i.e., a distinct asset). This means that the parties don't have to engage in costly bargaining over many rights to single attributes. The dissipation of value is at a minimum.

Asset ownership also implies that one, at least as a starting point, possesses the rights to unspecified, hitherto undiscovered uses of the asset. Thus, for this reason an entrepreneur may prefer to acquire ownership of an asset rather than acquire a specified, finite list of rights to uses of an asset. In other words, ownership is a low-cost means of allocating the rights to attributes of assets that are discovered by the entrepreneur/ owner. In a well-functioning legal system, ownership of an asset normally implies that the courts will not interfere when an entrepreneur/ owner discovers and captures new attributes of his asset. A consequence of this is that it is not normally required that the entrepreneur/ owner enters into costly negotiation with those agents that are affected his discovery. In this way, too, the dissipation of value is minimized. However, there is also an

\footnotetext{
11 One obvious, but non-economic reason is that the legal system distinguishes between the law relating to contract and the law relating to ownership of assets.

12 In contrast, it not so easy to find a room for ownership in mainstream economics. This is typically accomplished by introducing the non-mainstream notion of bounded rationality, which means that contracts become incomplete, leaving a role for ownership (Grossman and Hart 1986; Hart and Moore 1990; Hart 1995). However, this literature is open to charges of working with ad hoc assumptions and even inconsistency (see Tirole 1999; Maskin and Tirole 1999).
} 
incentive effect of asset ownership. More specifically, asset ownership implies a legally recognized right to the income of that asset, including the right to income from discovered attributes. Thus, one function of ownership is the distinct incentive it provides for entrepreneurial discovery, particularly, of course, to the extent that this discovery goes beyond mere luck and requires effort. ${ }^{13}$

\section{Productive and D estructive Entrepreneurship}

So far our argument has been that the modern Austrian perspective on the economic process as one of entrepreneurial discovery (Kirzner 1973, 1997) dovetails with insights on property rights and ownership derived from the work of older Austrians and from property rights theorists such as Barzel (1997). This combination of ideas yields new insights in both entrepreneurship and property rights and ownership, as we have seen. A further implication relates to the distinction between productive and destructive entrepreneurship. In Austrian economics, there seems to be a general claim that all entrepreneurial discovery is socially beneficial (Mises 1949; Kirzner 1973).14 However, a property rights perspective reveals that this claim is unwarranted; the capture of rights over attributes may be socially harmful. It is therefore necessary to make a distinction between productive and destructive entrepreneurship.

As a general matter the capture of rights refers to taking control of attributes of assets. When such capture requires the use of resources for discovering new attributes and taking control over these without compensating others on the margin and in such a way that joint surplus (net social benefits) is reduced, we shall speak of "destructive entrepreneurship." Thus, discovering new morally hazardous ways of behavior (Holmström 1982), effecting hold-ups (Williamson 1996), and inventing new ways of engaging in rent-seeking activities relative to government (Baumol 1990) are examples of destructive entrepreneurship in the sense that these represent the discovery of new attributes that decrease joint surplus. "Productive entrepreneurship" refers to the discovery of new attributes, where this discovery leads to an increase in joint surplus. For example, a franchisee may discover new local tastes that in turn may form the basis for new products for the entire chain; an employee may discover better uses of production assets and communicate this to the TQM team of which he is a member; a CEO may discover a new business concept; etc.

In the following section, we shall argue that many cooperative relations, involving potential gains from trade, are characterized by tradeoffs between productive and destructive entrepreneurial activities. Various types of economic organization, broadly conceived, arise in order to strike efficient tradeoffs.

\footnotetext{
13 See also Klein (1996) and Klein and Klein (2000). This links up with the emphasis in the Misesian tradition on the necessity of ownership for "calculation," that is, the formation of market prices for capital goods with many different uses (Mises 1936; Salerno 1999).

14 To some extent this is because entrepreneurship is only seen as an arbitrage activity, at least in the most influential Austrian work on the subject, namely Kirzner $(1973,1997)$.
} 


\section{Implications for Economic Organization}

\section{Economic O rganization in an Entrepreneur Economy}

In an entrepreneur economy, there are two basic problems that efficient economic organization must address in addition to those traditionally considered in the modern economics of organization (i.e., moral hazard and hold-up). The first such problem concerns the control of destructive entrepreneurial activities, that is, an agent's possibilities of discovering new attributes of assets that he will be able to control without making marginal payments to others and reducing joint surplus. For example, firms may delimit the use by employees of telephone and internet services, by closely specifying their use rights over the relevant assets. As that example suggests, firms are unlikely to be entirely successful in their attempt to curb such activities. Thus, creative employees may, for example, invent ways of covering their (mis-)use of the internet, which in turn may destruct additional value. However, the various constraints that firms impose on employees (or, more generally, contracting partners on each other) may have the side-effect that productive entrepreneurship is stifled (cf. Kirzner 1985).

More generally, a key problem of economic organization is to stimulate the productive discovery of new attributes of assets, through, for example, quality circles, letting employees spend a certain amount of company time on activities of their own choice, etc. This amounts to making the relation between principals and agents (a firm and its employees; a firm and its R\&D departments; a firm and its supplier, etc.) less completely specified. Thus, an important choice exists with respect to choosing tradeoffs between productive and destructive entrepreneurial activities. In the following section, we construct a simple, stylized example that involves this trade-off and discuss various implications of that example.

\section{Organizing A Productive Relationship}

Consider a productive relation between two agents, $X$ and $Y$, that involves the use of a multi-attribute asset. ${ }^{15}$ The relation can be organized so that $X$ is principal and $Y$ agent, or vice versa. Moreover, there are complementarities between the parties' activities. Because of these complementarities, there are gains from trade. The relation is governed by a contract, the degree of incompleteness of which is a choice variable. The contract terms that are stipulated in the (incomplete) contract can be perfectly enforced. We adopt this admittedly extreme assumption in order to abstract from those aspects of economic organization under incomplete contracting that turn on enforcement issues.

In principle, $\mathrm{X}$ and $\mathrm{Y}$ can write a complete contract. However, in the example we assume that this is never optimal. There are costs as well as benefits associated with contractual incompleteness, and, hence, an optimum level of incompleteness. Incompleteness is motivated by the Austrian assumption that if $X(Y)$ hires $Y(X)$ as 
an employee or a contractor, he cannot know all the possible attributes of the asset that $\mathrm{Y}(\mathrm{X})$ may discover. As we have argued, this provides the possibilities for productive as well as destructive entrepreneurship, where these possibilities can be constrained by contract terms.

When $X(Y)$ hires $Y$, he holds expectations (measured in certainty equivalents) about the consequences for the monetary joint surplus (henceforth, simply "joint surplus") of $Y^{\prime} s$ ( $\left.X^{\prime} s\right)$ productive and destructive entrepreneurial activities as functions of the degree of discretion $Y(X)$ is granted through the contract. Thus, although $X(Y)$ is not likely to be able to fully specify what the $Y(X)$ will discover, ${ }^{16}$ $X(Y)$ still holds a subjective expectation of the consequences for the joint surplus of the $Y$ 's (X's) entrepreneurship. ${ }^{17}$ Figure 1 maps the $X^{\prime}$ 's (Y's) expectations with respect to the impact on joint surplus of $Y^{\prime} s\left(X^{\prime} s\right)$ productive and destructive entrepreneurship.

\section{$X X X X X X X X$ Insert figure 1 here $X X X X X X X X$}

More specifically, the figure shows total benefits and costs of productive and destructive entrepreneurship as functions of the degree of contractual constraints. For the moment, it will suffice to think of "the degree of contractual incompleteness" in terms of the time that $Y(X)$ is allowed to work on his own ideas, using the asset(s) in any way he sees fit.

The P-curve thus shows the total benefits from productive entrepreneurship as a function of the free time $Y(X)$ is given. The claim is that, as $Y(X)$ is given more freedom, he will engage in more productive entrepreneurship, that is, he will discover more beneficial attributes of the productive asset(s) he operates. For example, he may discover new ways of making the assets more effective or new markets to which the asset's services may be deployed. We will assume that Y's ( $X$ 's) realization of some private benefit (i.e., a non-transferable utility) of engaging in productive entrepreneurial activities provides sufficient motivation for him.

Although these ideas are distinctly unconventional (at least in the context of the economics of organization), they are not unrealistic. For example, firms such as $3 \mathrm{M}$ allocate time to research employees that they are basically free to use in almost any way they see fit in the hope that this will produce serendipitous discoveries. $M$ any consulting firms do something similar. Of course, many industrial firms have known for a long time that the jobs of research employees must be constrained in different, and typically much looser, ways from those of employees with more routine tasks. The increasing emphasis on "empowerment" during the last decades reflects a real ization that employees derive a private benefit from controlling aspects of their job situation. And it is a key point in the total quality movement that

\footnotetext{
16 If he could do so, there would be no need for the agent's discovery.

17 This may be seen as akin to the assumption in the new property rights approach that although agents cannot foresee all contingencies, they still anticipate pay-offs probabilistically. Frank Knight (1921) argued that a key executive function is forming judgment of other people's judgment. This captures much of the idea of our construct here.
} 
delegating various rights to employees provides sufficient motivation for these employees to engage in activities that amount to finding ways to increase the mean and reduce the variance of quality (Jensen and Wruck 1994) - that is, what we call productive entrepreneurship.

The relation between total benefits and more free time is a strictly concave one. The decreasing marginal returns from new discoveries may be caused by the increasing difficulties of implementing the new discoveries, given that $X(Y)$ and the $Y(X)$ are constrained in terms of the time that is available for productive activities. Alternatively, $Y$ 's ( $X$ 's) attention is more focused on making valuable discoveries when he has less free time than when he has more.

In the absence of destructive entrepreneurial activities, the first-best simply is giving $Y(X)$ full freedom. However, in our Austrian set-up, the first-best cannot be reached because $X(Y)$ cannot completely constrain $Y^{\prime} s$ ( $\left.X^{\prime} s\right)$ destructive entrepreneurial activities. The D-curve shows X's ( $Y$ 's) expectations of $Y$ 's ( $X^{\prime}$ 's) destructive entrepreneurial activities as a function of being given more time that he can use as he sees fit. Thus, with increased discretion over multi-attribute assets, $Y$ $(X)$ will discover more new ways of controlling attributes, which increases his own benefit, but reduces expected joint surplus.

As drawn in figure 1, the optimum degree of contractual incompleteness is given by $\mathrm{Cl}^{*}$ where the contribution to joint surplus is at the maximum ( $\mathrm{S}^{*}$ ).

\section{Who Will Become the Principal and How Will the Surplus be Shared?}

So far, we have implicitly assumed that one of parties involved in the relation has comparative advantages in direction and that efficiency requires that he becomes the principal. This is consistent with standard mainstream principal-agent theory which also simply assumes that one of the parties is principal, but provides little or no justification for this assumption. However, our setup allows to determine who will become principal. This choice depends on four factors, namely the distribution of comparative advantages in direction (which influences productive entrepreneurship) and in monitoring (which influences destructive entrepreneurship), ${ }^{18}$ and on the distribution of comparative advantages in productive and destructive entrepreneurship. For example, with respect to direction, one of the parties may have a comparative advantage in finding the mostvalued uses of the other party's human capital, because he has superior knowledge of the market opportunities for the productive relation (as in Casson 1997). ${ }^{19}$ Consider figure $2 \mathrm{a}$.

XXXXXXXX Insert figure 2a here XXXXXXXX

\footnotetext{
${ }^{18}$ However, comparative advantages in monitoring, while surely relevant in actuality, is excluded by our assumption of zero cost enforcement of contract terms.

${ }_{19}$ Although we in the example focus on the agent's entrepreneurship, we may thus also ascribe entrepreneurial qualities to the principal as well.
} 
Figure $2 \mathrm{a}$ is based on the assumption that the D-curve describing how destructive entrepreneurship impacts on joint surplus as a function of contractual incompleteness is the same for both agents. However, their capacities for productive entrepreneurship is now assumed to differ. This is reflected in the two different $\mathrm{P}$-curves, $\mathrm{P}_{1}$ and $\mathrm{P}_{2}$. These map the parties' expectations with respect to the total benefit of $Y$ 's productive entrepreneurship as an agent when $X$ is principal, and the total benefit of $X$ 's productive entrepreneurship as an agent when $Y$ is principal, respectively.20 There are two different levels of contractual incompleteness, $\mathrm{Cl}_{1}$ * and $\mathrm{Cl}_{2} *$, and two corresponding levels of joint surplus, $\mathrm{S}_{1} *$ and $\mathrm{S}_{2}{ }^{*}$. In expectational equilibrium (Hayek 1937), that is, when the individuals' subjective expectations are consistent with each other, ${ }^{21} \mathrm{X}$ will assume the role of principal and hire $Y$ as his agent. This arrangement, where $X$ expects to receive $\left(\mathrm{S}_{1} *-\right.$ $\mathrm{S}_{2}{ }^{*}$ ) as his rent and $Y$ expects to receive $\mathrm{S}_{2}^{*}$, maximizes expected joint surplus. $\mathrm{Y}^{\prime} \mathrm{s}$ participation constraint is satisfied, since he receives a rent (which reflects his opportunity cost when he assumes the role of principal). He will thus accept the contract.

It is easy to see that comparative advantages in destructive entrepreneurship may also influence who will be principal and who will be agent. Consider figure $2 \mathrm{~b}$.

\section{$X X X X X X X X$ Insert figure $2 b$ here $X X X X X X X X$}

In figure $2 \mathrm{~b}, \mathrm{Y}$ has a comparative advantage in destructive entrepreneurship; hiring him as an agent dissipates more value for all levels of contractual incompleteness than hiring $X$ as an agent. Thus, it will maximize joint surplus to let him assume the role of principal.

\section{Who Will Own the Asset?}

We have assumed that the relation involves the use of a multi-attribute asset. However, we have said little about the nature of that asset, except that the agent's entrepreneurial activities takes place relative to this asset, and we have not discussed who should own the asset. The issues are related. If, for example, the relevant asset is the agent's inalienable human capital, he will, of course, also be the owner of the asset. However, it is more interesting to assume that some alienable asset, say, a "machine," is involved in the relation. We exclude the possibility of renting the machine, so either the principal or the agent will own it.

In order to understand who will become the asset owner, note that ownership confers the right to appropriate residual returns as well as the right to control the use of discovered new attributes of the asset to which one holds title. While the former function of ownership is highlighted in the modern economics of

\footnotetext{
20 The curves incorporate both the effect of direction and the effect of the parties' "innate" capabilities of productive entrepreneurship.

21 But not necessarily with the objective data. Thus, there may be ex post disequilibrium. Thus, to maintain an Austrian flavor to the analysis we don't assume common knowledge or rational expectations, in contrast to contract theory.
} 
organization, notably in the property rights approach, we have argued that the latter function is one that is associated with an Austrian approach. It is this latter function that we focus on here.22

Note that in figures 1 and 2 we have focused directly on monetary joint surplus. However, this excludes from consideration the fact that the agent realizes a private benefit from destructive as well as productive entrepreneurship. Per definition, such non-transferable utilities cannot enter into the determination of joint surplus. However, they may be important to understanding who, in the example, will have ownership to the machine.

Assume that the agents are in expectational equilibrium with respect to the impact on joint surplus of productive and destructive entrepreneurship with $X(Y)$ as principal and $\mathrm{Y}(\mathrm{X})$ as agent. While $\mathrm{Cl}_{1} *$ and $\mathrm{Cl}_{2} *$ are the preferred levels of contractual incompleteness of $X$ and $Y$, when acting as principals, these levels are not likely to be their preferred points when they act as agents. ${ }^{23}$ For example, an agent is likely to prefer to have less restrictions imposed on him than the principal prefers if the agent realizes more private benefit from engaging in destructive entrepreneurial activities than he gets from productive entrepreneurial activities.

Assume now that an agent whose preferred point differs from that of the principal is the owner of the machine. Because of his ownership of the machine, the agent has the power to veto the contract that the principal suggests. For example, the principal may demand that the machine is used in certain ways for a certain amount of time, and the agent may simply refuse this. Bargaining may take place, but is likely to be costly, because of the private nature of the agent's benefits. Value will not be dissipated by this sort of bargaining if instead the principal owns the asset. Thus, ownership is a means of implementing the principal's preferred degree of contractual incompleteness in a low-cost way. This illustrates both of the functions that we have argued is associated with ownership in an Austrian perspective, namely to stimulate entrepreneurship (i.e., implementing the preferred degree of contractual incompleteness of the party with the comparative advantage in directing) and to ease exchange (i.e., minimizing the dissipation of value through bargaining).

Our theory of ownership as a means of implementing a preferred degree of contractual incompleteness and therefore a certain combination of productive and destructive entrepreneurship has application beyond the determination of who, in a productive relation will be the owner. It can also cast light over the more general issue of why a certain agent earns a certain asset, irrespective of the productive and

\footnotetext{
22 Moreover, note that the modern property rights view of ownership as a means to appropriate residual returns is not relevant in the present context, since we have made no assumption about sunk-cost investments or costly effort.

23 More precisely, the agent's and the principal's preferred point will only coincide if the agent is completely indifferent between allocating time to destructive and productive entrepreneurship. If that is the case, he will always prefer the highest wage that he is offered by the principal, and the principal's and the agent's preferred points will coincide.
} 
contractual relations that he is involved in. The theory of ownership presented in Hart (1995) turns on the hold-up problem: One should own those assets that are complementary to one's (non-contractible) human capital investments, since this increases one's (ex post) bargaining power and thus the rents that may be expected from investments. This seems to be a less than general explanation: People own a lot of things the ownership of which cannot be explained by hold-up considerations. A nother insight, more akin to Austrian ideas, is to argue that those who discover new knowledge have an incentive to use it themselves because of the transaction costs of knowledge transfer. Given this, there is a general tendency for ownership of complementary assets to move to the knowledge source (rather than the other around), because knowledge is harder to trade than most other resources (Foss 1993; Casson 1997). The problem with this explanation is that it is does not allow to analytically distinguish between ownership and rental agreements. Our theory can do this, however.

For example, suppose that a car rental company put very few constraints in the contracts they offer renters, so that the latter could use the company's cars for the purpose of running a taxi business or a truck operation. Thus, the company does not much constrain productive and destructive entrepreneurship. In actuality, however, a car rental company will normally prefer to circumscribe in a relatively detailed way the possible productive and destructive entrepreneurship that the renter can engage in. For example, usually rental cars cannot be used for commercial purposes, among other things because the company fears that the car will not be driven in a proper way, and that this will diminish the demand of other renters for the car's services. Thus, in order to maintain demand and control externalities the company constrain the use of the car in many ways. However, a renter who wishes to use a rental car for entrepreneurial, commercial purposes is not likely to find the constraints imposed by the car rental company to be optimal. Hence, he may prefer to own the car in order to be able to impose his own preferred way of using the car, that is, he owns the car in order to carry out his own entrepreneurial plans. ${ }^{24}$

\section{The $M$ any Tradeoffs of Entrepreneurship and the Complex Structure of Economic O rganization}

In order to identify a fundamental problem, namely the optimal combination of productive and destructive entrepreneurship, and draw some implications of this (who will be the principal? who will own the asset?), we have suppressed many relevant tradeoffs by making extreme assumptions. For example, we have assumed that in principle all contractual constraints could be costlessly specified and enforced; the only reason why they may not all be specified was because this would suppress entrepreneurial discovery.

\footnotetext{
24 Of course, in this situation car rental companies may increase earnings by offering differentiated products, where rental fees and contractual constraints differ for different segments of the market, or new firms may arise to special-purpose segments of the market. However, even those firms that offer cars with fewer or other contractual constraints may be too constraining for some persons, particularly those who (expects that they) are likely to discover yet unimagined activities (i.e., entrepreneurs). They will still want to become owners.
} 
However, in the presence of costs of drafting contracts and measuring and enforcing contractual compliance this is an unrealistic assumption. In actuality, even the most routine-based job cannot be fully comprehensively described and monitored (Knight 1921), so that the agent will always have some possibilities of exercising entrepreneurship, for example, discovering ways of using tools in new ways, new ways of working slightly slower or slightly faster, etc. As argued earlier, such entrepreneurship may have both a productive and a destructive component. The impact of entrepreneurship on joint surplus is dependent on the types of the constraints that are imposed on the agent.

In practice, the trade-off may be regulated by limiting the budget to which the agent has access (Jensen and Meckling 1992), the activities that he can engage in (Holmström 1989), the people with whom he can work (Holmström and Milgrom 1990), the type of equipment to which he has access, and how he is allowed to operate that equipment (Barzel 1997). For example, regulating with whom an agent is allowed to interact clearly influences destructive as well as productive entrepreneurship; on the one hand, it may lead to destructive collusion among agents (as in Holmström and Milgrom 1990), on the other hand it may lead to the generation of new ideas.

Defining and monitoring constraints are clearly costly activities, that is, they are costly in terms of the principal's opportunity cost. This means that many margins will rationally be left open; the problem is then one of choosing the optimal constraints to impose on the agent(s). Because of entrepreneurship, this is an inherently difficult undertaking. Thus, imposing certain constraints on an entrepreneurial agent may lead to his discovery of new margins on which he engage in destructive entrepreneurship - activities that may be worse in terms of their impact on monetary joint surplus than those which the constraints seek to curb (Cheung 1969). This is a basic, potential trade-off that a forward-looking principal must consider.

\section{Other Theories of Economic Organization}

As already indicated, the approach of this paper is in several ways different from the mainstream in the economics of organization. Thus, we have sidestepped the issue of motivating the agent by means of explicit incentives by assuming that the agent realized a private benefit from having the freedom to engage in entrepreneurial activities that provide sufficient motivation for him to engage in these activities. This is not because we consider explicit incentives unimportant, but rather because we think the assumption that the agents can be (partly) motivated by being given more influence over their job situation is a realistic one (and a neglected one, too).

This also indicates how our approach differs from the new property rights approach (Hart 1995) and the transaction cost approach (Williamson 1996). In both 
of these two approaches it is assumed that contractual incompleteness is usually dominated by contractual completeness in terms of welfare. ${ }^{25}$ In contrast, we have argued that attempts to write complete contracts may lead to entrepreneurial activity, including productive entrepreneurial activity, may be curbed. Thus, contracts are incomplete in our story, not because of contract drafting costs (as in, e.g., Crocker and Reynolds 1993), but because transacting individuals rationally choose to leave contracts incomplete. The optimal degree of incompleteness of contracts is thus explained in completely different ways. Moreover, in contrast to the new property rights approach, the role of ownership is not so much to be a bargaining chip in situations of bilateral monopoly, but rather is a means by which an entrepreneur may implement and enforce his preferred degree of contractual incompleteness in a low-cost way (e.g., decide on organizational structure). Thus, the role of ownership in our story is to stimulate entrepreneurship and ease exchange. In contrast, while investments are usually influenced by the allocation of ownership in the property rights approach, entrepreneurship is not a relevant consideration in this approach.

In spite of these differences, our approach is related to some other approaches and contributions in the contemporary economics of organization. Most notably, we stress the inspiration from the works of Barzel $(1987,1994,1997)$. In particular, Barzel's (1987) endogenization of who will become entrepreneur (i.e. principal) is close in spirit to the present paper, although Barzel's story puts all the emphasis on incentives and the opportunity costs of monitoring (see also Khalil and Lawarrée 1995). Aghion and Tirole's (1997) paper emphasizes the role of delegation in fostering incentives, and also stress that the delegation of authority has not only incentive effects, but also influences the agent's participation. Delegation thus raises the agent's utility. In contrast, agents dislike being overruled by the principal. These assumptions are close in spirit to our basic assumption that agents derive private benefits from being less constrained in their job. The assumption in our approach that agents may discover multiple attributes of the assets with which they work may also be seen as an entrepreneurial version of the multi-task agency models of Holmström and Milgrom (1991). Finally, our idea of ownership as the principal's instrument for implementing his preferred degree of contractual incompleteness is akin to Holmström's (1999) point that ownership is important in the context of the theory of the firm, not because it diminishes exposure to hold-up per se, but rather because it allows the owner/manager to impose his preferred incentive systems, rules and regulations on employees.

\section{Conclusion}

In most of mainstream economics, “... there is no room for the entrepreneurial discovery process not only in the sense that no opportunities for pure profit can

25 Although important recent work has demonstrated that the first-best may be achieved even under incomplete contracting, given certain constraints on renegotiation design (e.g., one party has all the bargaining power) (Aghion, Dewatripont and Rey 1994). 
possibly exist, but also in the sense that the model precludes all Knightian uncertainty that might affect the character of the individual decision" (Kirzner 1997: 70). This is also the case of the modern economics of organization. In contrast, by starting from Austrian and property rights ideas, we have argued that it is possible to make room for entrepreneurial activities in the economics of organization, and that such an approach can pose new questions and give new answers (e.g., who will assume the role of principal and who of agent?), and can give new answers to traditional questions (e.g., who will own the asset?).

We began by arguing that from an Austrian perspective, the contracting space is in principle always open-ended, since there are always margins to discovered over which agents may optimize their gains. The property rights approach argues that the presence of measurement costs and costs of enforcement means that not all attributes will be enforced and not all actions will be monitored. However, principals may still constrain agents' opportunities for entrepreneurial discovery in various ways, for example, by deciding on which equipment an agent can work with and how, etc. In fact, we have argued that principals will usually optimally constrain entrepreneurial agents, since the discovery of new margins will not necessarily lead to increases in joint surplus; unproductive rent-seeking may well be one outcome of entrepreneurial activity. In such a setting, we argued that the function of ownership is to give the principal the bargaining power to implement his preferred combination of productive and destructive entrepreneurship, while still leaving a rent for the agent. This partly accounts for structures of ownership and for the structure of contracts. More generally, the property rights systems in firms are structured so as to handle the many dimensions of the basic combination of productive and unproductive entrepreneurial activities. Fourth, the combination of productive and unproductive entrepreneurial activities are not the sole determinants of economic organization, including ownership structures; entrepreneurial abilities, monitoring and much else also matter.

Much more work remains to be done on the connection between entrepreneurship and economic organization. Only few contributions exist on the subject (e.g., Barzel 1987; Gifford 1999). However, it is increasingly recognized by business people and business academics that a major contemporary challenge for firms is to install entrepreneurship at levels of the organization (e.g., Day and Wendler 1998). Clearly, the mainstream economics of organization has much to offer here, for example, with respect to the design of compensation schemes and commitment problems in entrepreneurial organizations. The suggestion of this paper is that ideas from economics on entrepreneurship should also be included in such an intellectual enterprise. These ideas may well be those of the Austrian school of economics. 


\section{References}

Aghion, Philippe and Jean Tirole. 1997. "Formal and Real Authority in Organization," Journal of Political Economy 105: 1-29.

Aghion, Philippe, Mathias Dewatripont, and Patrick Rey. 1994. "Renegotiation Design With Unverifiable Information," Econometrica 62: 257-282.

Alchian, Armen A. 1965. "Some Economics of Property Rights," in idem. 1977. Economic Forces at W ork, Indianapolis: Liberty Press.

Barzel, Yoram. 1987. "The Entrepreneur's Reward for Self-Policing," Economic Inquiry 25: 103-116.

Barzel, Yoram. 1994. "The Capture of Wealth by Monopolists and the Protection of Property Rights," International Review of Law and Economics 14: 393-409.

Barzel, Yoram. 1997. Economic Analysis of Property Rights, 2nd ed., Cambridge: Cambridge University Press.

Barzel, Yoram. 1999. "Transaction Costs and Contract Choice," manuscript.

Baumol, William J. 1990. "Entrepreneurship: Productive, Unproductive and Destructive," Journal of Political Economy 98: 893-919.

Böhm-Bawerk, Eugen von. 1881. "Whether Legal Rights and Relationships are Economic Goods," in Hans Sennholz, ed. Shorter Classics of Böhm-Bawerk. South Holland: Libertarian Press.

Casson, Mark. 1997. Information and O rganization. Oxford: Oxford University Press.

Cheung, Stephen S.N. 1969. "The Structure of a Contract and the Theory of a N onExclusive Ressource," Journal of Law and Economics 10: 49-70.

Coase, Ronald H. 1960. "The Problem of Social Cost," in idem. 1988. The Firm, the $M$ arket and the State. Chicago: University of Chicago Press.

Crocker, Keith J. and Kenneth J. Reynolds. 1993. "The Efficiency of Incomplete Contracts: An Empirical Analysis of Engine Air Force Procurement," Rand Journal of E conomics 24: 126-146.

Day, Jonathan and Jim Wendler 1998. "The New Economics of Organization," The M cKinsey Quarterly, no. 1: 4-18.

Demsetz, Harold. 1964. "The Exchange and Enforcement of Property Rights," in idem. 1988. O wnership, Control, and the Firm. Oxford: Basil Blackwell.

Demsetz, Harold. 1967. "Toward a Theory of Property Rights," in idem. 1988. O wnership, Control, and the Firm. Oxford: Basil Blackwell.

Demsetz, Harold. 1983. "The Neglect of the Entrepreneur," in Joshua Ronen, ed. Entrepreneurship. Lexington: Lexington Press.

Demsetz, Harold. 1988. "Profit as a Functional Return: Reconsidering Knight's Views," in idem. 1988. Ownership, Control and the Firm. The Organization of Economic A ctivity, vol. 1. Oxford and N ew York: Blackwell. 
Demsetz, Harold. 1988b. "A Framework for the Study of Ownership," in idem. 1988. O wnership, Control, and the Firm: The Organization of Economic Activity, vol. 1. Oxford and New York: Blackwell

Foss, Nicolai J. 1993. "Theories of the Firm: Contractual and Competence Perspectives," Journal of Evolutionary Economics 3: 127-144.

Foss, Nicolai J. 1994. "Precursor of Property Rights Economics: Ludwig von Mises," in idem. 1994. The A ustrian School and M odern Economics: Essays in Reassessment. Copenhagen: Munksgaard.

Foss, Nicolai J. 1999. "The Use of Knowledge in Firms," Journal of Institutional and Theor etical Economics 155: 458-486.

Foss, Nicolai J. 2000. "Game Theory and Austrian Economics," Review of Austrian Economics 13: 41-58

Foss, Kirsten and Nicolai J. Foss. 2000a. "Assets, Attributes and Ownership," forthcoming in International Journal of the Economics of Business.

Foss, Kirsten and Nicolai J. Foss. 2000b. "Theoretical Isolation in Contract Theory: Suppressing Margins and Entrepreneurship," forthcoming in the Journal of Economic M ethodology.

Gifford, Sharon. 1992. "Allocation of Entrepreneurial Attention," Journal of Economic Behavior and Organization 19: 265-284.

Gifford, Sharon. 1999. "Limited Attention and the Optimal Incompleteness of Contracts," Journal of Law, Economics and Organization 15: 468-486.

Grossman, Sanford, and Oliver Hart. 1986. "The Costs and Benefits of Ownership: A Theory of Lateral and Vertical Integration," Journal of Political E conomy 94: 691719.

Hart, Oliver. 1995. Firms, Contracts and Financial Structure. Oxford: Clarendon Press.

Hart, Oliver and Bengt Holmström. 1987. "The Theory of Contracts," in Truman F. Bewley. 1987. Advances in Economic Theory. Fifth World Congress. Cambridge: Cambridge University Press.

Hart, Oliver and John Moore. 1990. "Property Rights and the Nature of the Firm," Journal of Political Economy 98: 1119-1158.

Hayek, Friedrich A. von. 1937. "Economics and Knowledge," in idem. 1948. Individualism and Economic O rder. Chicago: University of Chicago Press.

Hayek, Friedrich A. von. 1945. "The Use of Knowledge in Society," in idem. 1948. Individualism and E conomic O rder. Chicago: University of Chicago Press.

Hayek, Friedrich A. von. 1968. "Competition as a Discovery Procedure," in idem. 1978. New Studies in Philophy, Economics, Politics and the History of Ideas. London: Routledge.

Holmström, Bengt. 1982. “Moral Hazard in Teams," Bell Journal of Economics 13: 324 340.

* Holmström, Bengt. 1999. "The Firm as a Subeconomy," Journal of Law, Economics and Organization 
Holmström, Bengt and Paul Milgrom. 1990. "Regulating Trade Among Agents," Journal of Institutional and Theoretical Economics 146: 85-105.

Holmström, Bengt and Paul Milgrom. 1991. "Multitask Principal-Agent Analyses: Incentive Contracts, Asset Ownership, and Job Design," Journal of Law, Economics, and Organization 7: 24-52.

Jensen, Michael C. and William Meckling. 1992. "Specific and General Knowledge and Organizational Structure," in Lars Werin and Hans Wijkander, eds. Contract Economics. Oxford: Basil Blackwell.

Jensen, Michael C. and Karen Wruck. 1994. "Science, Specific Knowledge and Total Quality Management," Journal of A ccounting and Economics 18: 247-287.

Khalil, Fahad and Jacques Lawarrée. 1995. "Input versus Output Monitoring: Who Is the Residual Claimant," Journal of Economic Theory 66: 139-157.

Kirzner, Israel M. 1973. Entrepreneurship and Competition. Chicago: University of Chicago Press.

Kirzner, Israel M. 1985. "The Perils of Regulation," in idem. 1985. D iscovery and the Capitalist Process. Chicago: University of Chicago Press.

Kirzner, Israel M. 1997. "Entrepreneurial Discovery and the Competitive Market Process: An Austrian A pproach," Journal of Economic Literature 35: 60-85.

Klein, Peter G. 1996. "Economic Calculation and the Limits of Organization," Review of A ustrian Economics 9: 3-28.

Klein, Peter G. and Sandra Klein. 2000. “Do Entrepreneurs Make Predictable Mistakes: Evidence From Corporate Divestitures," M anuscript.

Knight, Frank H. 1921. Risk, U ncertainty, and Profit. New York: August M. Kelley.

* Knight, Frank H. 1924. "Some Fallacies in the Interpretation of Social Cost," in George J. Stigler and Kenneth Boulding, eds. 1952. Readings in Price Theory.....

Lachmann, Ludwig M. 1986. The M arket as an Economic Process. London: Macmillan.

Littlechild, Stephen. 1986. "Three Types of Market Process," in Richard N. Langlois, ed. Economics as a Process: Essays in the $\mathrm{N}$ ew Institutional Economics. Cambridge: Cambridge University Press.

Loasby, Brian J. 1999. Knowledge, Institutions, and Evolution in Economics. London: Routledge.

* Macleod, ....Bentley. 1994. “.....," Canadian Journal of E conomics

Maskin, Eric and Jean Tirole. 1999. “Unforeseen Contingencies, Property Rights, and Incomplete Contracts," Review of Economic Studies 66: 83-114.

Menger, Carl. 1871. Principles of Economics. N ew York: N ew York University Press.

Minkler, Alanson P. 1993. "Knowledge and Internal Organization," Journal of Economic Behavior and Organization 21: 17-30.

Mises, Ludwig von. 1936. Socialism. Indianapolis: Liberty Press.

Mises, Ludwig von. 1949. H uman A ction. London: William Hodge.

O'Driscoll, Gerald P. and Mario Rizzo. 1985. The Economics of Time and Ignorance. Oxford: Basil Blackwell. 
Ricketts, Martin. 1987. "Rent Seeking, Entrepreneurship, Subjectivism, and Property Rights," Journal of Institutional and Theoretical Economics 143: 457-466.

Salerno, Joseph. 1999. "The Place of Mises' Human Action in the Development of Modern Economic Thought," The Q uarterly Journal of A ustrian Economics 2: 3565.

Shackle, George L.S. 1972. Epistemics and Economics. Cambridge: Cambridge University Press.

Tirole, Jean. 1999. "Incomplete Contracts: Where Do We Stand?," Walras-Bowley Lecture," Econometrica 67: 741-81.

Umbeck, John. 1981. "Might Makes Rights: A Theory of the Formation and Initial Distribution of Property Rights," Economic Inquiry 19: 38-59.

Williamson, Oliver E. 1996. The Mechanisms of Governance. Oxford: Oxford University Press.

*Witt, Ulrich. 1998. 
Figure 1

Basic case

Total benefits and costs

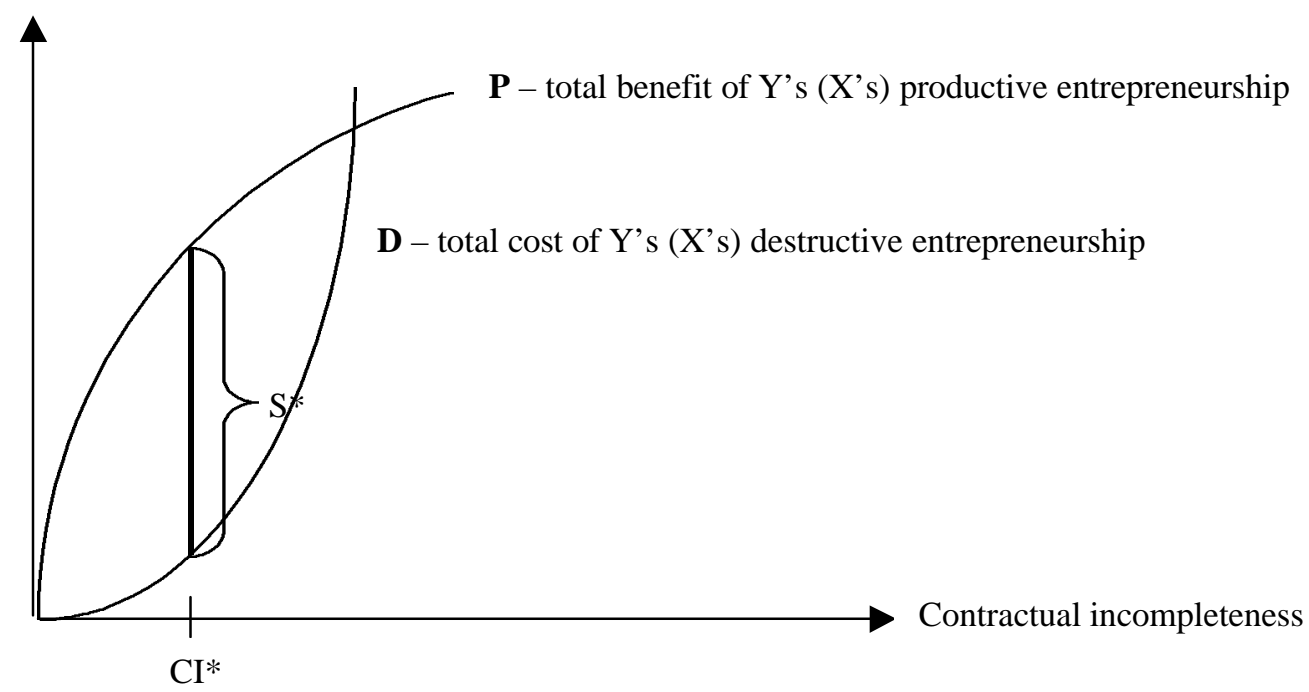

Figure 2a

D etermining who should be principal; allowing $P$ to vary

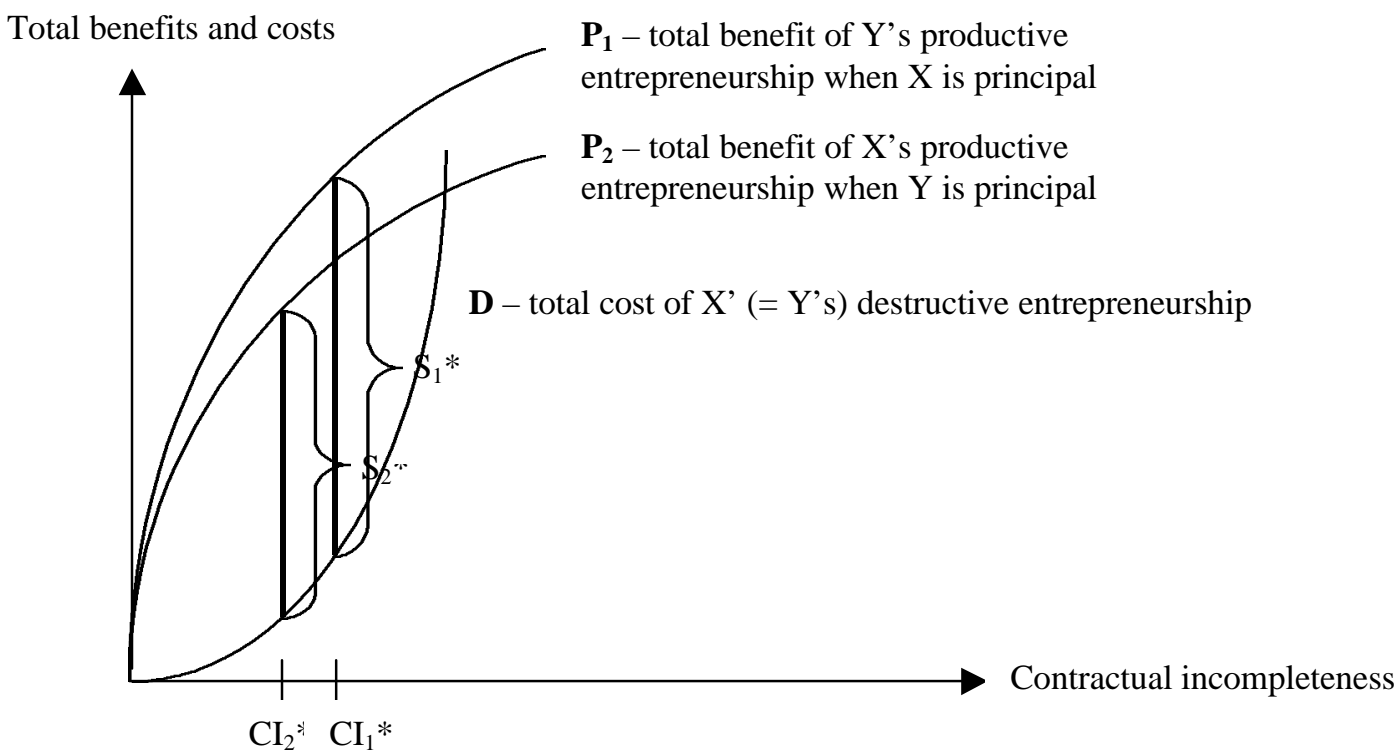


Figure $\mathbf{2 b}$

D etermining who should be principal; allowing $D$ to vary

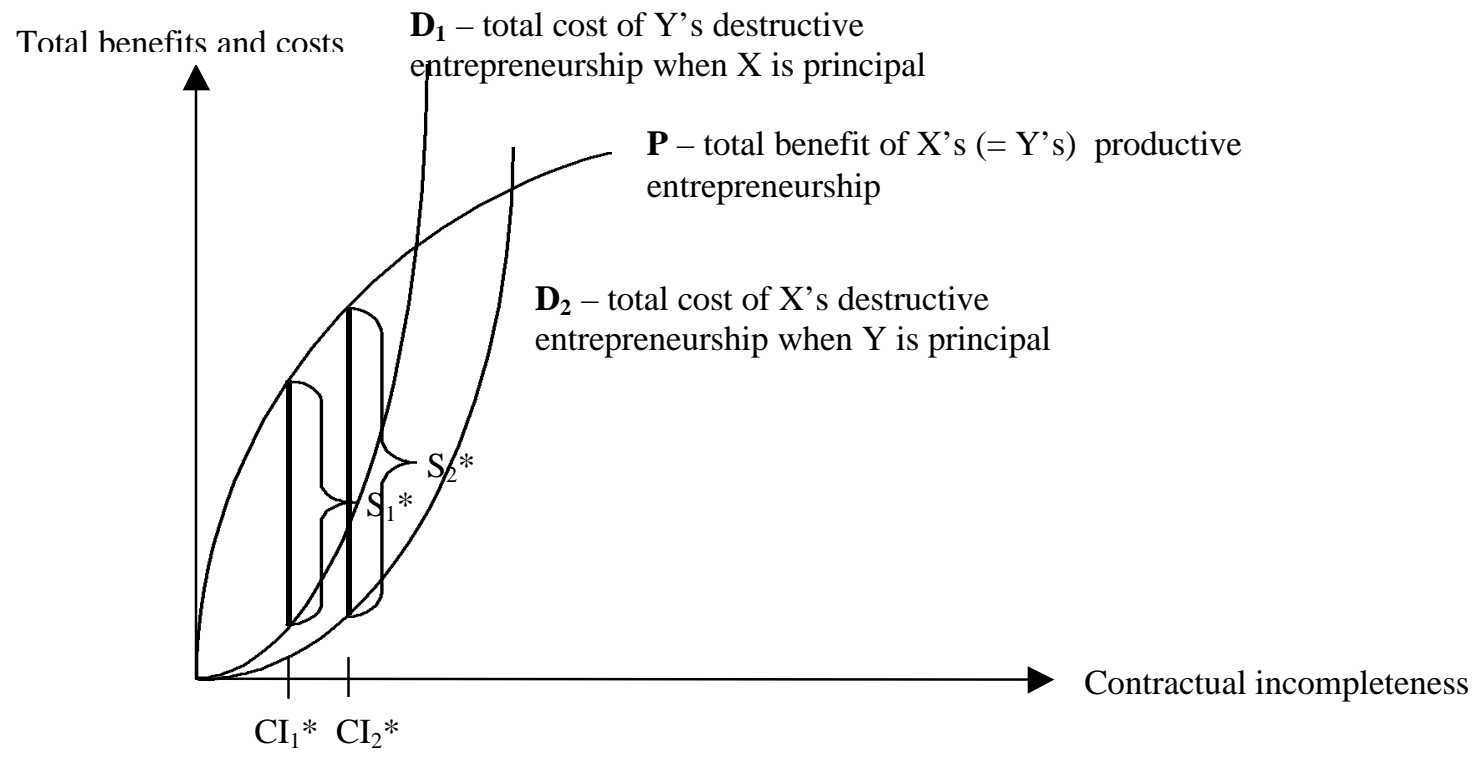


